УДК 611.127:591.4-092.9

DOI 10.11603/me.2414-5998.2020.4.11375

V. M. Baibakov ${ }^{1}$
ORCID https://orcid.org/0000-0001-8632-103X

L. V. Hryhorenko ${ }^{2}$

ORCID https://orcid.org/0000-0002-9517-5975

Scopus Author ID 57201492622

${ }^{1}$ Dnipro Medical Institute of Traditional and Non-Traditional Medicine

${ }^{2}$ Dnipropetrovsk Medical Academy

\title{
IMPLEMENTATION OF ECOLOGICAL EDUCATION TO THE TEACHING PROCESS ON DISCIPLINE “HYGIENE AND ECOLOGY” FOR ENGLISH- SPEAKING SIX YEAR STUDENTS
}

\author{
В. М. Байбаков ${ }^{1}$, Л. В. Григоренко ${ }^{2}$ \\ ${ }^{1}$ Дніпровський медичний інститут традиційної і нетрадиційної медицини \\ ${ }^{2}$ ДЗ «Дніпропетровська медична академія МОЗ України» \\ ВПРОВАДЖЕННЯ ЕКОЛОГІЧНОЇ ОСВІТИ ПРИ ВИКЛАДАННІ \\ ДИСЦИПЛІНИ «ГІГІЄНА ТА ЕКОЛОГІЯ» АНГЛОМОВНИМ \\ СТУДЕНТАМ VI КУРСІВ
}

\begin{abstract}
The article adduces the features of training English-speaking students of graduate courses in the departments of hygienic profile at the medical schools. It was established that the following issues remain difficult at the implementation of ecological education for English-speaking students in the departments of hygienic profile: adaptation of current national normative documents to the educational process; application of international regulatory standards and recommendations of US EPA and WHO international organizations, if compared with domestic counterparts; at the teaching of lectures and practical classes, especially on ecological-dependent pathology, should be taking into account deontological, national and religious peculiarities of foreign students. The results of the survey conducted among English-speaking six year students (36 students in total) showed that 40 to $60 \%$ from total number of academic hours in the discipline should be assigned to independent work in a medical university, according to (25 and $19.4 \%)$ respondents. At the same time, the time budget for IWS preparation differs: for theoretical subjects, on average, a foreign student spends 1-2 hours (30.5\%), while less than 1 hour (22.2 \%) preparation for clinical disciplines. Majority of English-speaking students (53 \%) believe that the amount of time they spend preparing for classes depends on their interest in learning a particular discipline. This is due to the complexity of this or that topic, as $55.5 \%$ of respondents noted. The other $30.8 \%$ of foreigners do not think so, which indicates about low motivation this quota of senior students to study in Medical Higher Education Institutions, and requires more careful attention of teachers in creating interest in the study of hygiene disciplines.
\end{abstract}

Key words: hygienic profile; student’s independent work; English speaking students; environmental education.

Анотація. У статті показано особливості підготовки англомовних студентів старших курсів на кафедрах гігієнічного профілю у вищих медичних навчальних закладах. Встановлено, що проблемними питаннями при впровадженні екологічної освіти для англомовних студентів на кафедрах гігієнічного профілю залишаються такі: адаптація чинних вітчизняних нормативних документів до навчального процесу; застосування міжнародних нормативних стандартів та рекомендацій міжнародних організацій US EPA і BOO3, при порівнянні з вітчизняними аналогами; викладання лекційного матеріалу і практичних занять, особливо екологозалежної патології, повинно бути з урахуванням деонтологічних, національних і релігійних особливостей іноземних студентів. Результати проведеного анкетування серед англомовних студентів 6 курсів (загалом - 36 осіб) свідчать, що на самостійну роботу у медичному виші повинно відводитися від 40 до 60 \% від загальної кількості навчальних годин 3 дисципліни, як вважають (25 і 19,4 \%) респондентів. При цьому бюджет часу на підготовку СРС відрізняється: для теоретичних дисциплін у середньому іноземний студент витрачає 1-2 год (30,5 \%), тоді як на підготовку до клінічних дисциплін - менше 1 год (22,2 \%). Більшість англомовних студентів (53 \%) вважає, що кількість часу, яку вони витрачають на підготовку до заняття, залежить від їхньої зацікавленості у вивченні конкретної дисципліни. Це обумовлено складністю тієї чи іншої теми заняття, як відмітили 55,5 \% респондентів. Інші 30,8 \% іноземців так не вважають або не замислювалися, що свідчить про низьку мотивацію цієї квоти студентів старших курсів до навчання у медичному виші, та потребує більш ретельної уваги викладачів у створенні зацікавленості до вивчення дисциплін гігієнічного профілю.

Ключові слова: гігієнічний профіль; самостійна робота студента; англомовні студенти; екологічна освіта.

(C) V. M. Baibakov, L. V. Hryhorenko 
Introduction. Today, based on our experience work with foreign students, problem of adaptation the normative legal documents in the field of preventive medicine in teaching subject "Hygiene and Ecology" in Englishspeaking students of higher educational establishments in Ukraine remains insufficiently solved. First of all, this is caused by the necessity of forming teacher an environmental awareness in the vast majority of foreign students, since environmental pollution is a great problem in the countries of Eastern Europe. It is dealt with by many ministries and departments, while in the territory of our country these issues are taken care of: agricultural policy, emergencies, water committees, and finally - by State Consumer Service.

Novelty of the study is to substantiate technology of introduction environmental education during teaching of hygiene disciplines in English to foreign students in the senior courses. Primary, sociological survey of English-speaking six year students was carried out and focused on the quality assessment organization of independent students' work (IWS) in the Department of Hygiene and Ecology.

Analysis of recent research. Technology of teaching foreign students by the basics of hygienic $[1,2,6]$ and clinical thinking $[10,12,13]$ is proposed in the given works. Researches of domestic scientists $[11,14]$ have shown the role of student scientific society in the professional-oriented training of future physicians.

The aim - to analyze modern technologies of preparation English-speaking senior courses students in the departments of hygienic profile.

Methods. There were used such methods: sociological survey, comparative analysis, medical (scientific) discourse, descriptive, bibliographic.

We used questionnaire in the research, which contained 16 questions reflecting the opinion of respondents regarding their relationship to different types of IWS. The questionnaire includes questions according to which can be characterized: types of IWS, which are provided during mastering disciplines in higher medical education establishments; budget of time (in \% of the total number of academic hours from the discipline) spent by a foreign student on IWS; budget of time spent by the student during study of clinical and theoretical disciplines, accordingly, for each classroom or extra-auditory class; to establish interest of foreign medical students in the study of a particular discipline, depending on the complexity of subject; whether students need teacher's advice when preparing for IWS topic; what sources do the students use in order to find answers to IWS control questions; wishes of student to improve organization of IWS in the department, etc.

Results. Specificity of Ukrainian experience is that when teaching hygiene subjects, it is necessary to take into account firstly the national characteristics of foreign students. Generally, material that is quite simple to understand for a domestic student can cause some difficulties in English-speaking students. As example can show several situational tasks in the hygiene disciplines used in assessing theoretical training of English-speaking students [3].

Task 1. What standard document regulates quality of potable water at the centralized water supply?

A. "Sanitary rules on the device and maintenance of wells and springs" (1975)

B. ISO 2.2.4-171-10 "Hygienic requirements to drinking water for human consumption"

C. Sanitary rules and norms No. 4630-88 "Protection of superficial water objects from pollution"

D. ISO 7525:2014 "Drinking water. Requirements and methods of control quality"

E. ISO 2761-84 "Sources of centralized economicdrinking water supply"

A fairly simple test task is incomprehensible to average English-speaking student who has no idea which of the following national regulations is valid in the field of drinking water. In particular, at the absence in six year English-speaking students of textbooks, assessing students' self-study such as theoretical preparation for practical training is difficult. Some difficulties arise when considering topic about non-communicable diseases of aquatic origin, which are presented in the national textbook "Municipal Hygiene” edited by E. H. Honcharuk [4] for domestic students. On the other hand, if we compare domestic and world regulatory bases for drinking water quality assessment, a whole range of chemicals $2^{\text {nd }}$ class of hazard, which are characterized by potentiating a toxic action - summation effect - are absent in the list of chemicals from Ukrainian National Standard ISO 2.2.4-171-10. However they are recommended by US EPA and WHO: cyanides, dichloromethane, 1.2 dichloroethane, 1.1.1 - trichloroethane.

Comparing method of hygienic assessment a food security of the population, according to the current "Norms of physiological needs population of Ukraine in the basic nutrients and energy" 2017 [5] with similar WHO standards, we can conclude that average European consumes twice, or even twice more calories than average Ukrainian. According to professor Serdiuk A. M., there is a rapid decline in consumption basic nutrients in our country [8]: 
- meat and meat products - on $56 \%$;

- milk and dairy products - on $45 \%$;

- eggs - on $35.7 \%$;

- fish and fishery products - on $48.6 \%$;

- vegetables, fruit, berries - on $47.3 \%$;

- vegetable oil - on $19 \%$.

Therefore, according to the current "Norms of Physiological Need Population of Ukraine..." [5] 2017, a domestic student from any educational institution aged 18-29 years must consume on average 2450 kilocalories of energy supplied to the body with food; 67 grams of protein, 68 grams of fat, 392 grams of hydrocarbons. Compared to similar WHO standards, when consuming on average 2500 kilocalories of energy, maximum fat intake should be 90 grams per day, which is almost twice more than national standard.

Situational problems in assessing nutritional status of the population, drawn up taking into account the national dishes of English-speaking students from Eastern Europe [9], showed that a diet of average foreign student is twice more caloric as the national one, if it is estimated according to "Norms of Physiological Needs for Ukrainian Population ...”: 4833 calories (on 1.97 times higher than national standard), 115.4 grams of fat (on 1.69 times higher than national standard).

Daily average diet of 18-29 years old man [9]:

CALORIES FAT

Breakfast

Organic Swiss Muesli (grams)

Rich Tea

Fish Steaks in Butter Sauce, 150g

Celery, per average stick

96

42

$159 \quad 15$

50

Second breakfast

Liver and Onion Bake, 400g

Macaroni Cheese, 360g

626

576

Creamed Garlic and Herb Dressing $\mathbf{1 0 4}$

Salad Cream

89

Egg Fried

Fruit Drink

427

121

Dinner

Turkey and Ham Sandwich

Egg Mayonnaise and Sausage

Tomato, Lettuce and Dressing

Cream of Mushroom

Lemon Tea

$90 \%$ Fat Free Soft and Creamy

Cheese, 200g

Cherry Cake

Tea

Apricot Fruit Pies

280

300

141

180

180

256

170

Fresh Cream Raspberry $\underline{\text { Supper }}$

Greek Yoghurt 150g

20014.0

Low calorie Grapefruit and Lemon 345ml $17 \quad 0$

Egg and Tomato with Salad Cream

462

When conducting classes with English-speaking students, especially during presentation of lecture material, in order to create environmental awareness, in our opinion, it is necessary to get acquainted with real environmental situation in Ukraine. When considering the topic: "Sanitary protection of soil. Methods and Schemes of Solid Waste Cleaning" I often use examples from Sergey Ryzhenko textbook "Medical Secret. Notes of practicing doctor" [7].

I can't resist not quoting one of the book's quotes: "Residents of the legendary Igren in Dnipropetrovsk once, I recall a former summer resort - from time to time rebel violently against the proximity of a landfill. Especially if the wind is blowing in their direction. Today, every citizen can understand them in the current state of sanitary cleaning up the city. So this is just household waste ... " It's a pity, so put it down, you can point out the students themselves.

Finally, I would like to add that some students take the information used to solve situational tasks almost literally. That is, mastering the practical skills of hygienic assessment situation with using national regulations, adapted to English classes, requires constant thoughtful work of a foreign student and persistence of the teacher.

In order to establish attitude of English-speaking students to the organization of independent work at the department of Hygiene and Ecology, we conducted a sociological survey of six year students. To the question "What types of students' independent work (IWS) are envisaged in mastering disciplines in the higher medi-

3.5 cal education?” $52.7 \%$ of students said that it was in-class and out-of-class work; $19.4 \%$ believe that it is only an in-class work; $13.8 \%$ indicate out-of-class 2.9 work and only $13.8 \%$ - do not know. In particular, 0 according to the opinion of foreign students of senior courses on independent work in higher medical edu25 cation should be allocated from 40 to $60 \%$ from total
30 number of academic hours in the discipline, as noted 25 and $19.4 \%$ of respondents. To the third question "Should be the same percentage of hours spent for working independently in the study of clinical and theoretical disciplines?” $67 \%$ of English speaking students answered "yes"; $25 \%$ "no" and only $2.7 \%$ of students do not know.

Results of the survey clearly show that on average, for the preparation of each class in theoretical subjects, the vast majority of foreign students spend 2-3 hours 
in 6 year of study, while in clinical disciplines - 1-2 hours (30.5\%). At the same time, English-speaking students spendless time $1-2$ hours (30.5\%) on prepa- ration for each non-academic study of theoretical subjects, while less than 1 hour (22.2\%) on preparation for clinical disciplines (Figure 1, 2).

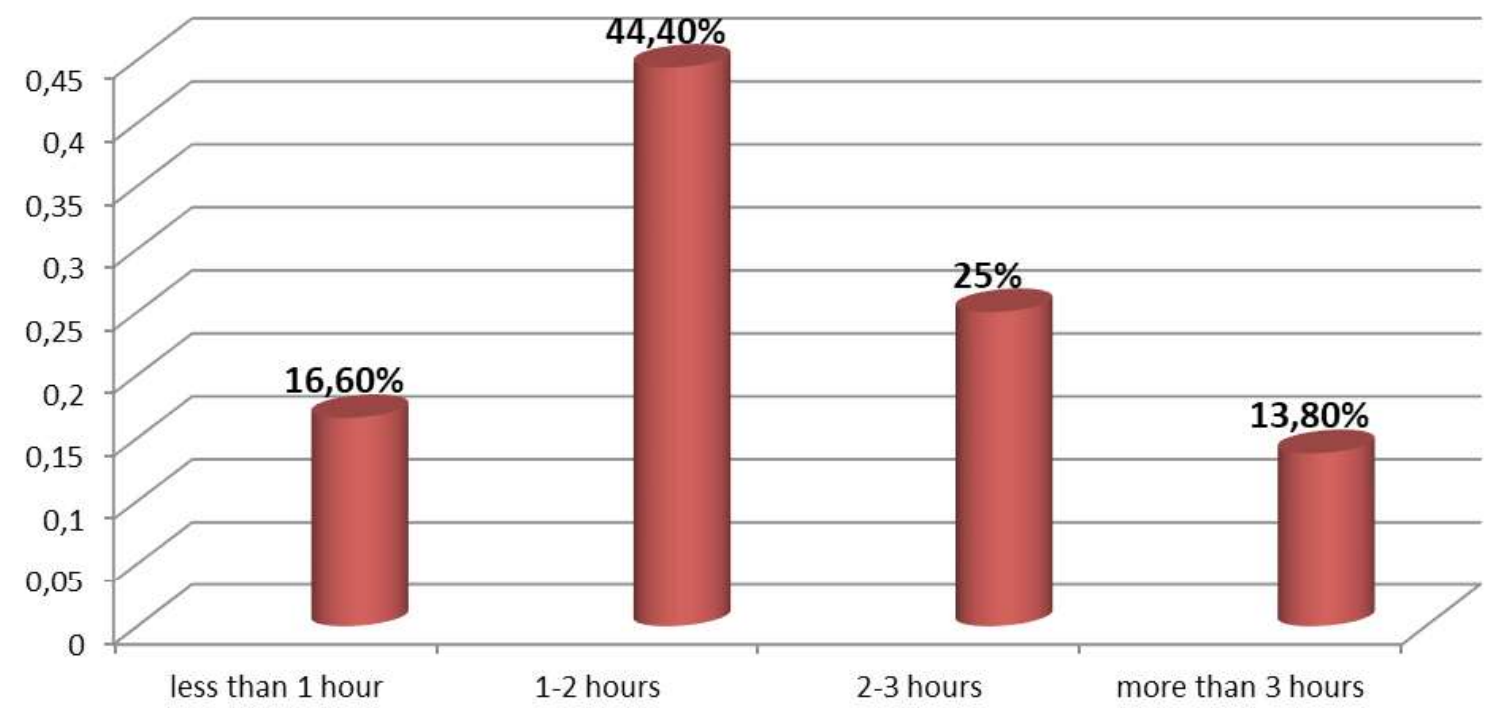

Figure 1. Budget of time 6 year English-speaking students for preparation each classes in the theoretical disciplines, \%.

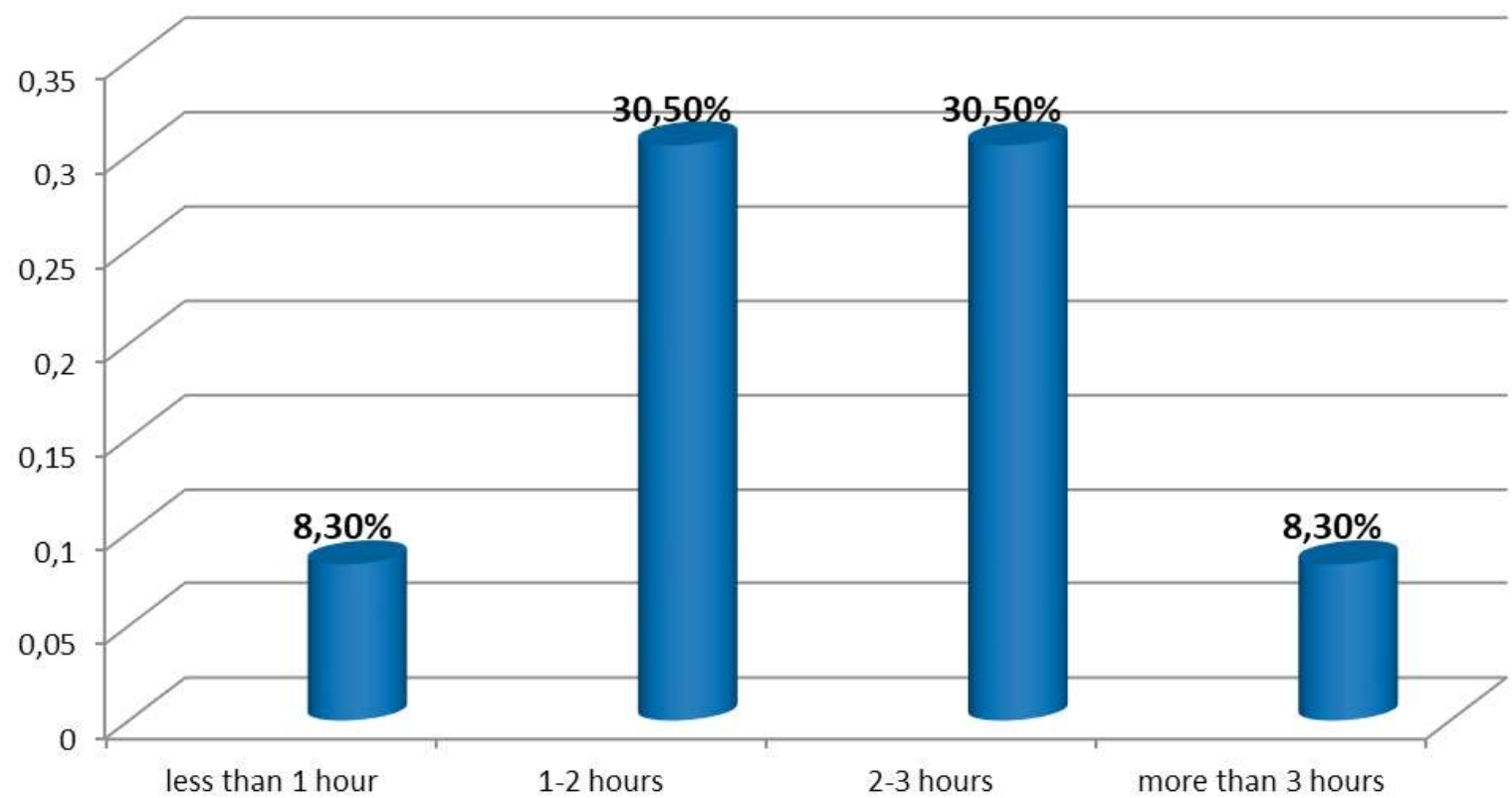

Figure 2. Budget of time 6 courses English-speaking students for preparation each classes in the clinical disciplines, \%.

On the positive side, almost all students (53 \%) believe that amount of time they spend preparing for classes depends on their interest in learning a particular discipline; $30.5 \%$ think that it is not dependent, and $17 \%$ do not think. This is due to the fact that amount of time students spend preparing for the class depends on the complexity topic of the class, as noted $55.5 \%$ of respondents. Other students (17\%) think, that it does not depend on the complexity of topic or did not think so (13.8 \%).
Among the major types of IWS offered at the department, $55.5 \%$ of English-speaking students prefer to solve situational problems; $13.8 \%$ - preparation of presentations; $17 \%$ - note taking; $2.7 \%$ - preparation of abstracts, $13.8 \%$ - other types of IWS (student scientific circles, olympiads, competitions of student scientific works, etc.) (Fig. 3).

It draws attention that in the opinion of foreign student control of mastering material of topics, study of which is provided out-of-class, should be carried 


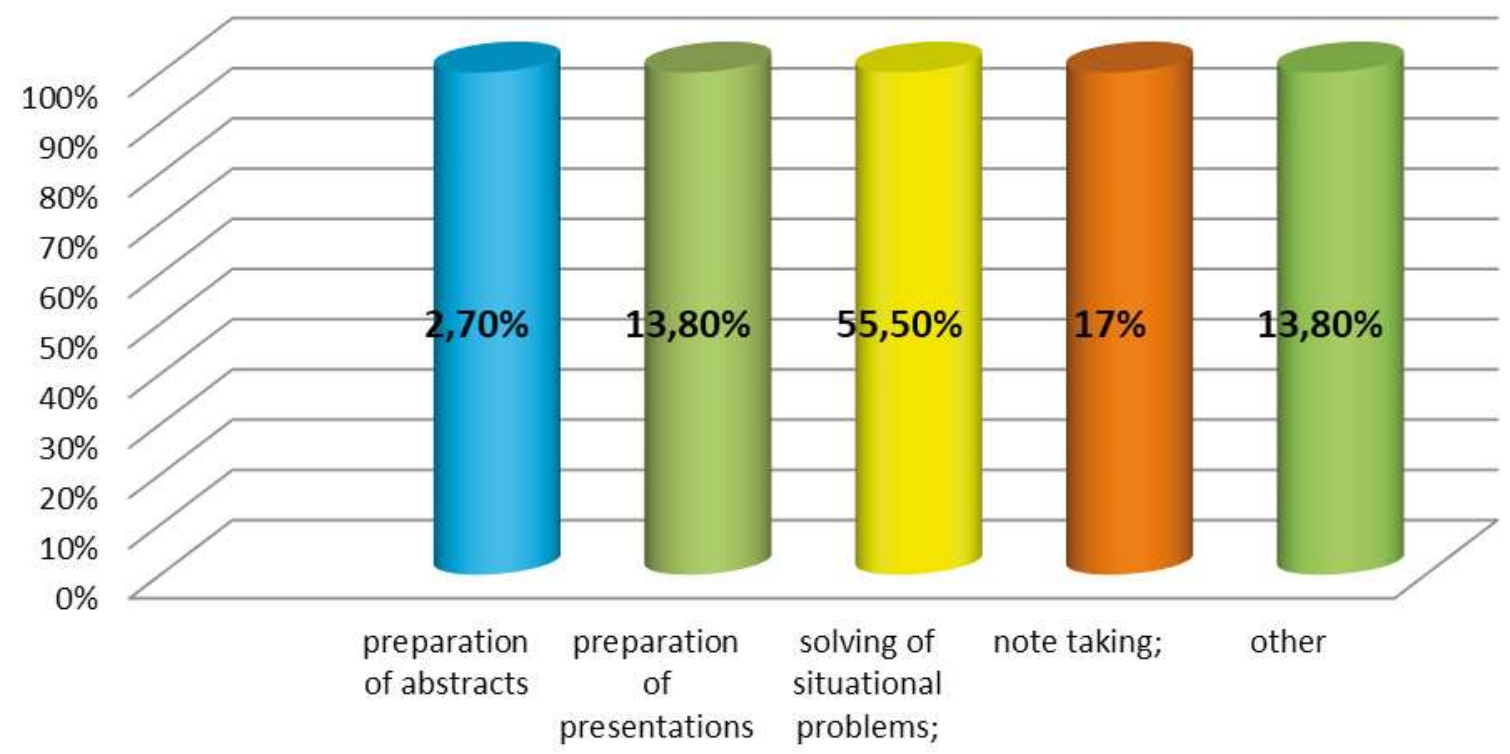

Figure 3. Respondents' answers to the question: "What types of independent work do you do?”

out: when conducting final lesson from the discipline $(19.4 \%)$; in practical classes from separate module (52.7\%); otherwise (11.1\%) or did not think (16.6\%). On the other side, vast majority of English-speaking students $(77.7 \%)$ require a guidance of teachers when mastering IWS. The minority of students (13.8\%) does not need guidance of teachers and $8.3 \%$ does not know. On the other hand, it is more convenient for foreign students to find answers for control questions on the topics of IWS: from Internet (36 \%); in the methodical manual developed by teachers in the department (33.3\%); in hygiene textbook (17\%); in other literary sources $(11.1 \%)$.

Generally, more than half of respondents (69.4\%) positively estimated self-employment as a form of study in the high medical establishment. Only 5 students (14\%) negatively related to IWS. More than 4 students $(11.1 \%)$ did not think about this issue. Among interviewed foreign students, 36 people participated in the survey, among them were 11 women (30.5\%) and 25 men (69.4\%). All students were studied in the 6 year in contract form of education.

Conclusions and Prospects for Research. 1. Summarizing the above said, it should be noted that the following issues remain the least resolved to date:

- adaptation of the existing national normative documents to the educational process in teaching of hygiene disciplines in English;

- application of international regulatory standards and recommendations of US EPA and WHO, when compared to similar domestic counterparts, does not always benefit the last one;
- teaching of lectures and practical classes, especially on ecological-dependent pathology, should take into account the deontological, national and religious characteristics of English-speaking students;

- system of assessment knowledge of English-speaking students, on a background of absence professional textbooks on hygienic disciplines for 6 year Englishspeaking students and reduction number of classroom hours, due to the increasing out-of-class hours, is imperfect and needs some correction.

2. Results of survey among six year English-speaking students (36 persons) indicate that from 40 to $60 \%$ from total number of academic hours in the discipline should be assigned to independent work in Medical School, as noted (25 and $19.4 \%$ ) of respondents. At the same time, the time budget for IWS preparation differs: for theoretical disciplines the foreign medical student spends 1-2 hours (30.5\%), while preparation of clinical disciplines takes less than 1 hour (22.2 \%). The majority of English-speaking students (53\%) believe that amount of time they spend preparing for classes depends on their interest in learning a particular discipline. This is due to the complexity topic of the lesson, according to $55.5 \%$ of respondents. Other $30.8 \%$ of foreigners, who do not think so, in our opinion, need more careful attention from the teacher in creating interest during studying disciplines of hygiene profile.

Prospects for further research: to find causal relationships for reducing interest of foreign students in the preparation classes from preventive medicine in the departments of hygiene profile using modern methods 
of mathematical data processing - determination of relationship between variables using parametric and nonparametric tables; dependencies by means of

\section{List of literature}

1. Абрамов С. В. Особливості підготовки англомовних студентів молодших і старших курсів кафедр гігієнічного профілю у вищих навчальних медичних установах / С. В. Абрамов, В. М. Байбаков, Л. В. Григоренко // Медична освіта. - 2019. - № 2. - С. 6-10.

2. Ашеров А. Т. Професійні якості спеціаліста - як компонент культури освіти / А.Т. Ашеров, В. І. Шеховцева, Ю. М. Полякова // Бюлетень НТУУ «КПІ»: філософія, психологія, освіта. - 2010. - № 2 (29). - С. 127-132.

3. Гігієна та екологія : навч. посіб. $з$ дисципліни «Гігієна та екологія» / [Н. І. Рублевська, О. А. Шевченко, Л. В. Григоренко та ін.]. - Дніпро : Герда, 2018. - 169 с.

4. Комунальна гігієна : підручник для студентів вищих медичних учбових закладів III-IV рівнів акредитації / під ред. проф. Є. Г. Гончарука. - К. : Здоров’я, 2006. - 789 с.

5. Наказ МОЗ України «Норми фізіологічних потреб населення України в основних харчових речовинах і енергії». - К., 2017. - 20 с.

6. Пузирьов Є. В. Система освіти студентів технічних університетів / Є. В. Пузирьов // Молодий вчений. 2015. - № 2 (17). - С. 299-302.

7. Рыженко С. А. Врачебная тайна. Записки практикующего доктора / С. А. Рыженко. - Днепр, 2007. - 57 с.

8. Сердюк А. М. 20 років Національної академії медичних наук України: підсумки та погляд у майбутнє / А. М. Сердюк // Журнал Національної академії медичних наук України. - 2013. - Т. 19, № 2. - С. 134-138.

9. Britain's best-selling calorie guide (A-Z of calories) / Gertrud Pertl, Hazel Sargent, Marilyn Cunningham, Brian Thomas. - Published by Octavo Publications Ltd. United Kingdom, 2010. - 100 p.

\section{References}

1. Abramov, S.V., Baibakov, V.M., \& Hryhorenko, L.V. (2019). Osoblyvosti pidhotovky anhlomovnykh studentiv molodshykh i starshykh kursiv kafedr hihiienichnoho profiliu u vyshchykh navchalnykh medychnykh ustanovakh [Features of training English-speaking students of junior and senior courses in the departments of hygienic profile in the higher educational medical institutions]. Medychna osvitaMedical Education, 2, 6-10 [in Ukrainian].

2. Asherov, A.T., Shekhovtseva, V.I., \& Poliakova, Yu.M. (2010). Profesiini yakosti spetsialista - yak komponent kultury osvity [Professional qualities of specialist - as a component of educational culture]. Biuleten NTUU «KPY»: filosofiia, psykholohiia, osvita - Bulletin of NTUU “KPI”: Philosophy, Psychology, Education, 2 (29), 127-132 [in Ukrainian]. one-factor and multivariate linear regression analysis, methods of multivariate statistics (discriminant and cluster analysis), probabilistic forecast.

10. Features of lecture preparation from the subject "Child's surgery, orthopaedy and traumatology" in the Ukrainian high medical institutions / V. A. Digtyar, V. M. Baibakov, D. M. Lukianenko [et al.] // Proceedings of the VIII International Scientific and Practical Conference "International Trends in Science and Technology". - Vol.2, December 25. - Poland: RS Global Sp. z O.O. Warsaw, 2018. - P. 21 - 24.

11. Role of lecture in the modern education system / S. B. Kramar, D. I. Nasarova, M. Yu. Zharikov [et al.] // European Applied Sciences. - 2015. - No. 4. - P. 22-24.

12. Scientific society in the field of child's surgery, orthopaedy and traumatology — as the basic element of professional training of medical students / V. A. Digtyar, V. M. Baibakov, S. V. Abramov [et al.] // International Periodic Scientifical Journal "Modern engineering and innovative technologies”. - Issue No. 6, Part 4. - Karlsruhe, Germany: Sergeieva\&Co, 2018. - P. 46-49.

13. Scientifical-methodical background system of medical students' education from discipline child's surgery, orthopaedy and traumatology in Ukraine / V. A. Digtyar, V. M. Baibakov, S. V. Abramov [et al.] // International Periodic Scientifical Journal "Modern engineering and innovative technologies”. - Issue No. 6, Part 4. - Karlsruhe, Germany: Sergeieva\&Co, 2018. - P. 37-45.

14. Student scientific society: Key role in the professional training of medical specialists in the higher medical schools / S. B. Kramar, D. I. Nazarova, Yu. V. Silkina [et. al.] // European Applied Sciences, 2016. - No. 11. - P. 17-20.

3. Rublevska, N.I., Shevchenko, O.A., \& Hryhorenko, L.V. (2018). Hihiiena ta ekolohiia: navchalnyi posibnyk z dystsypliny «Hihiiena ta ekolohiia» [Hygiene and ecology: textbook on the subject "Hygiene and ecology"]. Dnipro: Herda [in Ukrainian].

4. Honcharuk, E.H. (2006). Komunalna hihiiena. Pidruchnyk dlia studentiv vyshchykh medychnykh uchbovykh zakladiv III-IV rivniv akredytatsii [Municipal hygiene. Textbook for students of higher medical educational institutions of III-IV levels of accreditation]. Kyiv Zdorovia [in Ukrainian].

5. «Normy fiziolohichnykh potreb naselennia Ukrainy $u$ osnovnykh kharchovykh rechovynakh i enerhii» ["Norms of physiological needs of the population of Ukraine in the basic nutrients and energy"]. (2017). Nakaz MOZ Ukrainy Order of Ministry of Health of Ukraine [in Ukrainian]. 
6. Puzyrov, Ye.V. (2015). Systema osvity studentiv tekhnichnykh universytetiv [Education system for students of technical universities]. Molodyi vchenyi - Young Scientist, 2 (17), 299-302 [in Ukrainian].

7. Ryzhenko, S.A. (2007). Vrachebnaia taina. Zapiski praktikuiushchego doktora [Medical secrecy. Practicing doctor's notes]. Dnipro [in Russian].

8. Serdiuk, A.M. (2013). 20 rokiv Natsionalnoi akademii medychnykh nauk Ukrainy: pidsumky ta pohliad u maibutnie [20 years of the National Academy of Medical Sciences of Ukraine: results and a look into the future]. Zhurnal Natsionalnoi akademii medychnykh nauk Ukrainy - Journal of the National Academy of Medical Sciences of Ukraine, 19 (2), 134-138 [in Ukrainian].

9. Gertrud Pertl, Hazel Sargent, \& Marilyn Cunningham. (2010). Britain's best-selling calorie guide (A-Z of calories). Published by Octavo Publications Ltd. United Kingdom.

10. Digtyar, V.A., Baibakov, V.M., \& Lukianenko, D.M. (2018). Features of lecture preparation from the subject "Child's surgery, orthopaedy and traumatology" in the Ukrainian high medical institutions. Proceedings of the VIII International Scientific and Practical Conference "In- ternational Trends in Science and Technology”. Poland: RS Global Sp. z O.O. Warsaw.

11. Kramar, S.B., Nasarova, D.I., \& Zharikov, M.Yu. (2015). Role of lecture in the modern education system. European Applied Sciences.

12. Digtyar, V.A., Baibakov, V.M., \& Abramov, S.V. (2018). Scientific society in the field of child's surgery, orthopaedy and traumatology - as the basic element of professional training of medical students. International Periodic Scientifical journal "Modern engineering and innovative technologies”. 6 (4), 46-49.

13. Digtyar, V.A., Baibakov, V.M., \& Abramov, S.V. (2018). Scientifical-methodical background system of medical students'education from discipline child's surgery, orthopaedy and traumatology in Ukraine. International Periodic Scientifical Journal "Modern Engineering and Innovative Technologies”, 6 (4), 37-45.

14. Kramar, S.B., Nazarova, D.I., \& Silkina, Yu.V. (2016). Student Scientific Society: Key Role in the Professional Training of Medical Specialists in the Higher Medical Schools. European Applied Sciences.
Received 10.09.20

Recommended 15.09.20

E-mail address for correspondence: baybakov-vm@ukr.net 